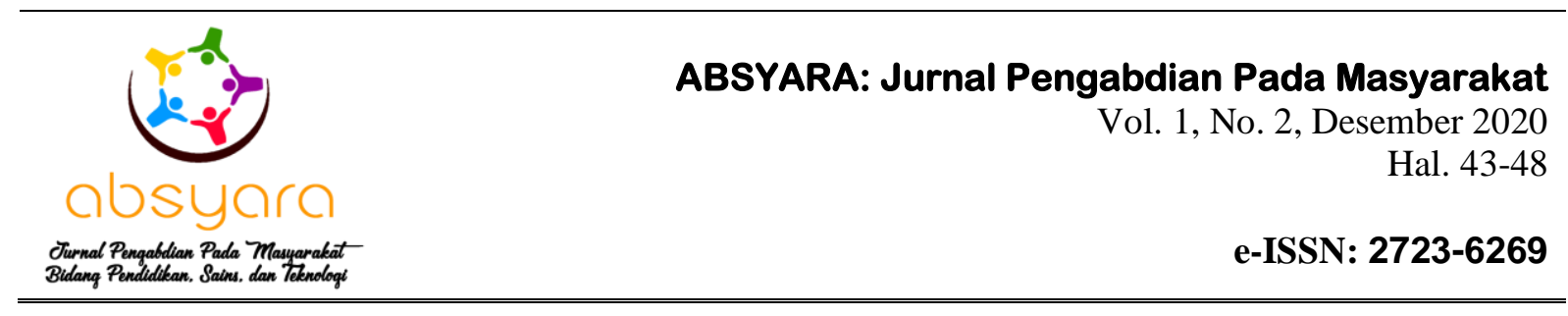

\title{
Pengembangan kompetensi profesional guru PAI melalui pemanfaatan teknologi informasi
}

\author{
Usman Sutisna*1, Mia Fitriah Elkarimah $^{2}$, Fery Rahmawan Asma ${ }^{3}$ \\ usmansutisna09@gmail.com*1 ${ }^{* 1}$,el.karimah@ gmail.com ${ }^{2}$, ferytijany489@ gmail.com³ \\ 1,2,3Program Studi Informatika, Fakultas Teknik dan Ilmu Komputer, Universitas Indraprasta
}

Received: 13 Oktober 2020

Accepted: 25 Desember 2020 Online Published: 31 Desember 2020

DOI: 10.29408/ab.v1i2.2629

URL: http://dx.doi.org/10.29408/ab.v1i2.2629

\begin{abstract}
Abstrak: Guru sebagai garda terdepan dalam pengembangan sekolah dan peserta didik harus memiliki berbagai macam kompetensi yaitu kompetensi pedagogik, kepribadian, sosial, dan profesional. Dalam kompetensi profesional, guru harus mampu memanfaatkan teknologi untuk mengembangkan diri dan berkomunikasi. Dalam rangka mendukung hal tersebut, kegiatan pengabdian pada masyarakat ini bertujuan untuk meningkatkan kompetensi profesionalisme guru Pendidikan Agama Islam (PAI) serta mendorong terwujudnya pembelajaran yang baik, khususnya dalam pembuatan naskah soal maupun materi yang memerlukan komponen bahasa Arab maupun Al-quran di dalamnya. Pelatihan ini diikuti oleh 35 guru agama dari 34 satuan Pendidikan Sekolah Dasar, baik negeri maupun swasta, yang tergabung dalam KKGPAI (Kelompok Kerja Guru Pendidikan Agama Islam) se-kecamatan Setiabudi. Metode pelatihan menggunakan metode ceramah dan demonstrasi atau peraktik langsung. Tugas tim pengabdian masyarakat sifatnya membantu para guru yang awalnya tidak memahami dan tidak bisa membuat soal berbahasa Arab secara komputerisasi menjadi bisa. Oleh karena itu para guru diharapkan dapat mengamalkan ilmunya dalam rangka tugas pengajaran di sekolah masing-masing khususnya dapat membuat soal PAI dan karya tulis dengan menggunakan bantuan komputer. Hasil dari kegiatan pengabdian masyarakat secara umum para guru agama yang tergabung dalam KKPAI Kecamatan Setiabudi sudah dapat membuat soal PAI berbahasa Arab menggunakan aplikasi komputer.
\end{abstract}

Kata kunci: Teknologi Informasi; Kompetensi Profesional Guru; Peyusunan Naskah Soal PAI

\begin{abstract}
Teachers are at the forefront of school, and students' development must have various competencies, namely pedagogical, personal, social, and professional competencies. In professional competence, educators must take advantage of information and communication technology to communicate and develop themselves. This community service activity aims to support the educator in gaining professional competence. Significantly to improve Islamic Religious Education (PAI) teachers' professional competence and encourage the realization of good learning, especially in making questions and materials that require Arabic Al-Qur'an components in it. Thirty-five religious teachers from 34 Elementary School Education units, both public and private, who are members of the KKGPAI (Islamic Religious Education Teachers Working Group) throughout the Setiabudi subdistrict attended this training. The training method uses lectures and demonstrations or direct practice. The community service team's task is to help teachers who initially do not understand and cannot make Arabian font or language with computers. Therefore, through in-teacher training, the educator can make PAI questions and written works in Arabic using computers. As the results of community service activities in general, religious teachers who are members of the KKPAI of Setiabudi district have made PAI questions in Arabic using a computer application.
\end{abstract}

Keywords: Information Technology; Teacher Professional Competence; Preparation of PAI Question Script 


\section{PENDAHULUAN}

Menurut Permen Dikbud nomor 16 tahun 2007, kompetensi guru merupakan kompetensi yang dikembangkan secara utuh dari empat kompetensi utama, yaitu kompetensi pedagogik, kepribadian, sosial, dan profesional. Seorang pendidik dituntut agar dapat mewujudkan kinerjanya secara tepat dan efektif. Dalam kompetensi pedagogik, kemampuan guru berupa keahlian dan keterampilan yang harus dimiliki oleh guru dalam menjalankan proses pembelajaran yang meliputi perencanaan pembelajaran, pelaksanaan pembelajaran sampai kepada pengevaluasian (Ismail, 2010). Dalam hal pengevaluasian, seorang guru dikatakan berkompeten apabila memahami teknik dan prosedur evaluasi, serta mampu melaksanakan evaluasi sehingga didapat hasil evaluasi yang digunakan untuk memperbaiki pembelajaran (Oermann \& Gaberson, 2009). Pelaksanaan evaluasi tersebut dimulai dari perencanaan evaluasi, pembuatan soal tes, mengolah dan menganalisis hasil tes hingga menginterpretasi dan menindaklanjuti hasil evaluasi pembelajaran (Sudjiono, 2009).

Evaluasi atau penilaian dalam sebuah pendidikan merupakan sesuatu yang wajib dilaksanakan karena penilaian merupakan bagian dari kurikulum pendidikan (Arikunto, 2009). Empat unsur dalam pendidikan yang membentuk suatu sistem dalam proses pendidikan yakni adanya; tujuan, isi atau materi, proses atau metode, dan evaluasi atau penialain. Untuk mendapatkan hasil dari proses pendidikan maka penilain dilakukan. Materi apapun yang diberikan kepada peserta didik, muaranya akan mendapatkan penilaian dari para guru yang memegang masing-masing materi tersebut (Arifin, Zainal, 2009). Melalui evaluasi atau penilaian, guru dapat mendeteksi kesulitan belajar yang dialami peserta didik (Arianti, dkk. 2020).

Di dalam proses evaluasi pembelajaran, pendidik diwajibkan untuk membuat beberapa hal, diantaranya membuat soal-soal pembelajaran, baik itu soal tugas harian maupun soal ujian semester. Pemanfaatan teknologi informasi dalam pembuatan tes atau soal ujian, terutama untuk Pendidikan Agama Islam (PAI) masih kurang (Harun \& Fauzan, 2019). Hal ini diakibatkan karena banyak guru PAI tidak memiliki pengetahuan tentang bagaimana memanfaatkan teknologi informasi dalam pembuatan. Selama ini pemanfaatan teknologi informasi hanya sebatas sebagai media pembelajaran. Penggunaan teknologi informasi sebagai media pembelajaran lebih efisien dan efektif, dan meningkatkan efektivitas guru dalam pembelajaran (Nugroho, dkk., 2019). Pembelajaran berbasis media digital pada pelajaran PAI juga membuat proses pembelajaran lebih menyenangkan dan dapat menunjang terhadap pengembangan PAI sendiri (Nugraha dkk., 2014).

Selama ini sebagaian besar guru PAI di kecamatan Setiabudi dalam menuliskan soal berbahasa arab, baik hadist dan ayat Al-quran menggunakan tulisan tangan kemudian dipoto atau discan, setelah itu baru dimasukkan ke file soal sebelum diprint. Hal ini dikarenakan guru PAI masih kesulitan dalam membuat soal yang mencantumkan ayat atau hadist dalam sebuah soal menggunakan bantuan teknologi komputerisasi. Oleh karena itulah perlu adanya sosialisasi dan pelatihan tentang bagimana cara menulis al-quran atau hadist dalam pembuatan naskah soal secara otomatis menggunakan komputer. Adapun tujuan dari kegiatan pengabdian kepada masyarakat ini yaitu mengembangkan kompetensi profesional guru melalui pelatihan penulisan bahasa arab atau huruf hijaiyah menggunakan aplikasi Quran in Word dalam membuat naskah soal PAI. 
Sutisna, U., Elkarimah, M. F., \& Asma, F. R. (2020). Pengembangan kompetensi profesional guru PAl melalui pemanfaatan teknologi informasi. ABSYARA: Jurnal Pengabdian Pada Masyarakat, 1(2), 9-14. DOI: 10.29408/ab.v1i2.2629

\section{METODE PELAKSANAAN}

\section{Waktu dan tempat}

Pengabdian pada masyarakat ini dilaksanakan dari bulan September - November 2019. Tempat pelaksanaan pelatihan di SDN Menteng Atas 14 Pagi yang beralamat di Jl. Minangkabau Dalam No.11 Kelurahan Menteng Atas Kecamatan Setiabudi, Jakarta Selatan.

\section{Prosedur pelaksanaan}

Metode yang digunakan dalam pelaksanaan ini adalah ceramah dan demonstrasi atau pelatihan secara lanngsung. Metode ini digunakan karena dalam pelatihan lebih mudah dipahami oleh peserta pelatihan (Nahdi, dkk., 2020). Adapun tahap-tahap pelaksanaan kegiatan adalah sebagai berikut:

\section{Persiapan}

Pada tahap persiapan, dimulai dari sosialisasi program dan pembentukan tim pelaksana kegiatan. Setelah itu dilakukan koordinasi dengan pihak sekolah dan pihak KKPAI (Kelompok Kerja Guru Pendidikan Agama Islam) dan mengurus perizinan kegiatan. Setelah itu menyusun proposal kegiatan.

\section{Pelaksanaan}

Tim melakukan pelatihan kepada seluruh guru-guru agama dengan menyampaikan materi tentang pembuatan naskah soal PAI dalam menulis. Kegiatan penyuluhan ini dilakukan dengan memberikan pengetahuan mengenai cara menginstal setup Quran in Word dari internet ke PC Personal Komputer. Lalu memberikan informasi mengenai cara penggunaan setup quran yang sudah terinstall tersebut dalam rangka penyusunan soal PAI. Terakhir peserta akan dibantu untuk mengoperasikan keyboard PC berbahasa arab untuk memudahkan pengetikan soal berbahasa arab (huruf hijaiyah).

Setelah melakukan pelatihan, tim melakukan pendampingan kepada guru-guru dalam rangka memberikan bantuan tentang cara install Quran in Word dan hal-hal yang berhubungan dengan tujuan kegiatan di atas, sehingga dengan pendampingan tersebut maka peserta pelatihan dapat terbantu.

\section{Evaluasi}

Evaluasi dilakukan dengan cara mengobservasi naskah soal yang dibuat para guru pada saat Ujian Akhir Semester Genap yang dilaksanakan perkiraan bulan November 2019.

\section{HASIL DAN PEMBAHASAN}

\section{Hasil}

Dari hasil pelaksanaan kegiatan pengabdian pada masyarakat di SDN Menteng Atas 14 Pagi didapatkan hasil seperti terlihat pada tabel 1. Berikut ini: 
Tabel 1. Hasil kegiatan pengabdian pada masyarakat

\begin{tabular}{|c|c|c|c|c|}
\hline No & Hari, Tanggal & Kegiatan & Peserta & Hasil \\
\hline 1 & $\begin{array}{l}\text { September } \\
2019\end{array}$ & $\begin{array}{ll}\text { - } & \text { Observasi awal dari } \\
\text { soal UTS mata } \\
\text { pelajaran PAI } \\
\text { - } \\
\text { Rapat koordinasi dan } \\
\text { pembentukan tim } \\
\text { PKM }\end{array}$ & Dosen & 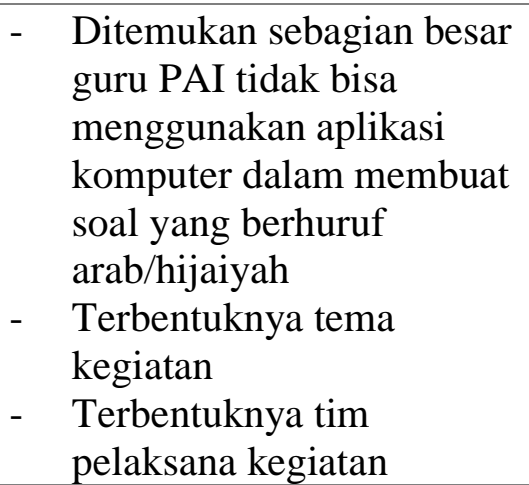 \\
\hline 2 & Oktober 2019 & 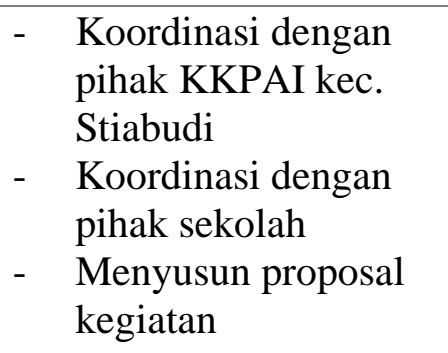 & $\begin{array}{l}\text { - Tim Dosen } \\
\text { - Pihak KKPAI } \\
\text { - Kepala sekolah } \\
\text { SDN Menteng } \\
\text { Atas } 14 \text { Pagi }\end{array}$ & $\begin{array}{ll}\text { - } & \text { Mendapat kesepakatan dan } \\
\text { dukungan dari pihak } \\
\text { KPPAI } \\
\text { - } \\
\text { Mendapat izin dari pihak } \\
\text { sekolah } \\
\text { - } \\
\text { Terbentuknya proposal } \\
\text { kegiatan }\end{array}$ \\
\hline 3 & $\begin{array}{l}11-13 \\
\text { November } \\
2019\end{array}$ & $\begin{array}{l}\text { Mempersiapkan alat } \\
\text { dan bahan kegiatan } \\
\text { pelatihan }\end{array}$ & - Tim Dosen & $\begin{array}{l}\text { - } \quad \text { PPT materi pelatihan } \\
\text { - } \quad \text { Software pelatihan }\end{array}$ \\
\hline 4 & $\begin{array}{l}16 \text { November } \\
2019\end{array}$ & $\begin{array}{l}\text { Pelaksanaan kegiatan } \\
\text { pelatihan dan } \\
\text { pendampingan }\end{array}$ & $\begin{array}{ll}\text { - } & \text { Tim Dosen } \\
\text { - } & \text { Peserta } \\
\text { pelatihan } \\
\text { sebanyak } \\
\text { 35 orang } \\
\text { guru PAI } \\
\text { dari } 34 \\
\text { sekolah }\end{array}$ & $\begin{array}{l}\text { Terbentuknya pemahaman } \\
\text { guru dalam menginstal } \\
\text { dan menggunakan aplikasi } \\
\text { untuk menulis bahasa } \\
\text { arab/hijaiyah untuk } \\
\text { pembuatan soal mata } \\
\text { pelajaran PAI }\end{array}$ \\
\hline 5 & $\begin{array}{l}26 \text { November } \\
2019\end{array}$ & $\begin{array}{ll}\text { - } & \text { Evaluasi hasil } \\
\text { kegiatan melalui soal } \\
\text { ujian semester }\end{array}$ & - Tim Dosen & $\begin{array}{l}\text { - Sebagian besar guru-guru } \\
\text { PAI di kecamatan } \\
\text { setiabudi sudah mampu } \\
\text { menggunakan aplikasi } \\
\text { Quran in Word }\end{array}$ \\
\hline 6 & $\begin{array}{l}28-30 \\
\text { November } \\
2019\end{array}$ & $\begin{array}{l}\text { - Penyusunan laporan } \\
\text { kegiatan }\end{array}$ & - Tim & - $\quad$ Laporan kegiatan \\
\hline
\end{tabular}




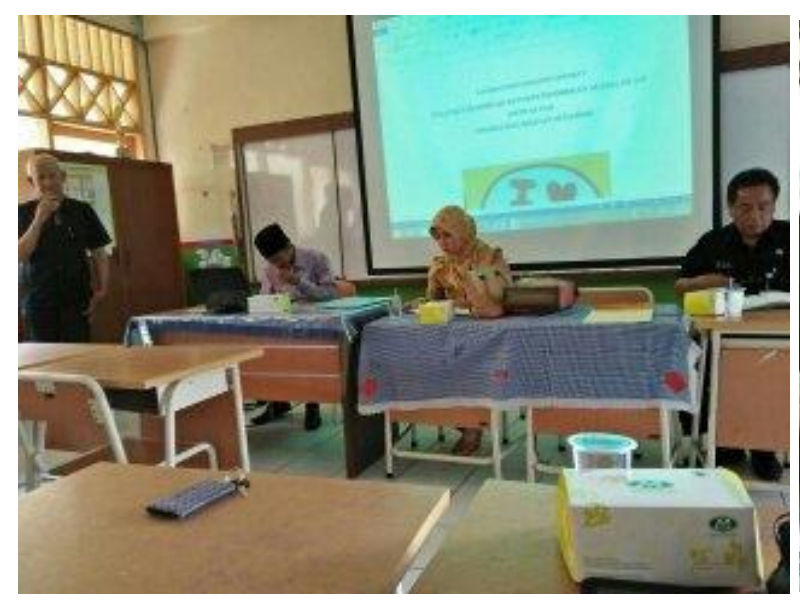

Gambar 1. Pembukaan Acara

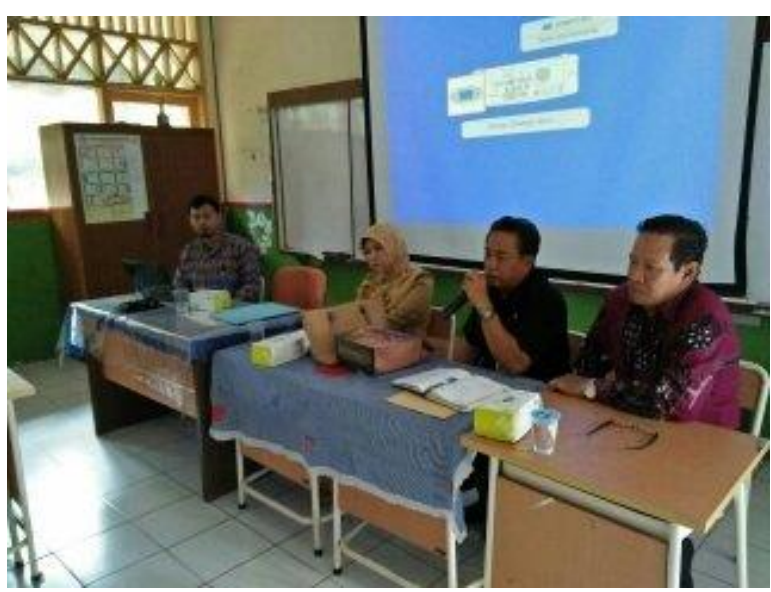

Gambar 2. Sambuatan Oleh Ketua KKGPAI Kecamatan Setiabudi

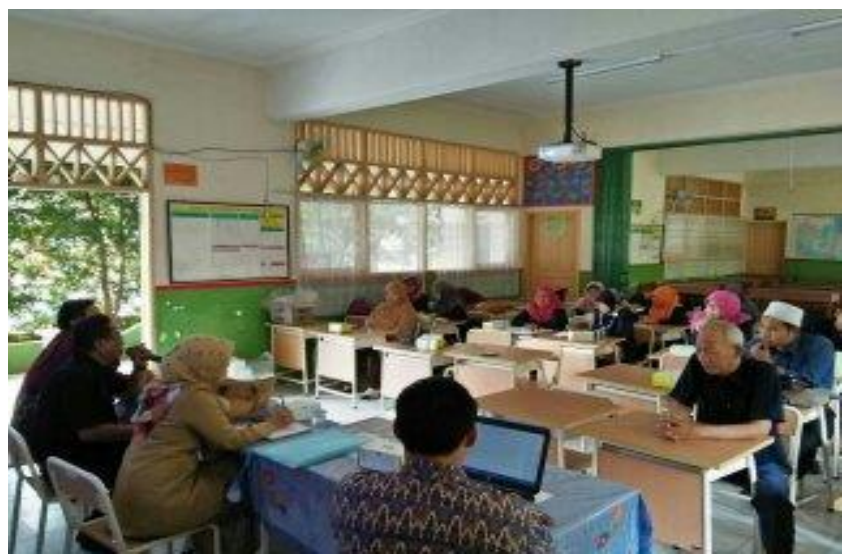

Gambar 3. Paparan Tim

\section{Pembahasan}

Pada tahap persiapan, dari hasil observasi awal didapatkan bahwa masih banyak guruguru mata pelajaran Pendidikan Agama Islam (PAI) belum mampu memanfaatkan teknologi informasi dalam membuat soal-soal ujian, terutama soal-soal dalam tulisan bahasa arab atau huruf hijaiyah. Selama ini soal-soal dibuat atau diketikkan oleh operator sekolah, itupun untuk soal yang menggunakan huruf arab atau hijaiyah dilakukan dengan manual atau tulis tangan, kemudian tulisan tersebut difoto dan discan, baru dimasukkan ke dalam file soal.

Pada tahap pelaksanaan kegiatan pelatihan dan pendampingan pemanfaatan teknologi informasi dalam menulis soal berbahasa arab atau huruf hijaiyah didapatkan ada beberapa guru yang masih kesulitan dalam menggunakan aplikasi yang diajarkan. Hal ini dikarenakan selain guru-guru tersebut sudah cukup berumur, kemampuan TIK guru tersebut juga rendah.

Tahap evaluasi dilakukan melalui pengamatan naskah-naskah soal ujian akhir semester yang dilakukan setelah pelatihan selesai. Hasil temuan didapatkan data bahwa hampir sebagian besar peserta pelatihan sudah menggunakan tulisan arab/hijaiyah melalui aplikasi Quran in Word. Adapun sekolah yang masih menggunakan cara manual dalam menulis bahasa arab atau huruf hijaiyah yaitu sekolah-sekolah yang pesertanya pada saat pelatihan memiliki kemampuan TIK yang rendah dan sudah berumur. 
Sutisna, U., Elkarimah, M. F., \& Asma, F. R. (2020). Pengembangan kompetensi profesional guru PAl melalui pemanfaatan teknologi informasi. ABSYARA: Jurnal Pengabdian Pada Masyarakat, 1(2), 9-14. DOI: 10.29408/ab.v1i2.2629

\section{SIMPULAN}

Hasil dari kegiatan pengabdian pada masyarakat ini adalah sebagian besar peserta yang mengikuti pelatihan sudah mampu menggunakan aplikasi Quran in Word dalam menyusun soal-soal ujian mata pelajaran PAI yang berbahasa arab atau menggunakan huruf hijaiyah. Sehingga dapat disimpulkan bahwa tujuan kegiatan ini bisa dikatakan sudah tercapai. Hal ini dapat dilihat dari antusiasme para peserta dalam mengikuti kegiatan pelatihan dan pendampingan ini. Bahkan ketua KKPAI mengharapkan pelatihan diadakan rutin setiap tahunnya.

\section{PERNYATAAN PENULIS}

Artikel atau tulisan ini belum pernah dipublikasikan pada jurnal apapun.

\section{DAFTAR PUSTAKA}

Arianti, B. D. D., Kholisho, Y. N., Ismatulloh, K., Wirasamita, R. H., Uska, M. Z., Fathoni A., Jamaluddin. (2020). Pelatihan computer based test (cbt) ujian nasional untuk siswa smk di lombok timur. ABSYARA: Jurnal Pengabdian Pada Masyarakat, 1(1), 22-23

Arifin, Zainal. 2009. Evaluasi Pembelajaran. Cetakan ke-4. Bandung: PT Remaja Rosdakarya.

Arikunto, Suharsimi. 2009. Dasar-Dasar Evaluasi Pendidikan. Jakarta : Bumiaksara.

Nahdi, D. S., Rasyid, A., \& Cahyaningsih, U. (2020). Meningkatkan kompetensi profesional guru melalui pengembangan media pembelajaran berbasis teknologi informasi. BERNAS: Jurnal Pengabdian Kepada Masyarakat, 1(2), 76-81.

Harun, I., \& Fauzan, M. (2019). Penggunaan teknologi informasi dan komunikasi dalam pembelajaran oleh guru pendidikan agama islam. AL-USWAH: Jurnal Riset dan Kajian Pendidikan Agama Islam, 1(2), 88-99.

Ismail, M. I. (2010). Kinerja dan kompetensi guru dalam pembelajaran. Lentera Pendidikan: Jurnal Ilmu Tarbiyah dan Keguruan, 13(1), 44-63.

Oermann, M. H., \& Gaberson, K. B. (2016). Evaluation and testing in nursing education. Springer Publishing Company.

Peraturan Menteri Pendidikan Nasional Republik Indonesia Nomor 16 tentang Standar Kualifikasi Akademik dan Kompetensi Guru. (2007). Jakarta: Kementrian Pendidikan Nasional

Nugraha, M. S., Supriadi, U., \& Anwar, S. (2014). Pembelajran pai berbasis media digital (studi deskriptip terhadap pembelajaran pai di sma alfa centauri bandung). J. Pendidik. Agama Islam-Ta'lim.

Sudjiono, Anas. 2009. Pengantar Evaluasi Pendidikan. Jakarta: Raja Prees.

Nugroho, B. T. T. A. (2019). Pemanfaatan teknologi informasi dalam pembelajaran pai di sd negeri candirejo. Jurnal PROGRESS: Wahana Kreativitas dan Intelektualitas, 7(1). 